\title{
Surface Sediments of the Pearl River Estuary (South China Sea) - Spatial Distribution of Sedimentological / Geochemical Properties and Environmental Interpretation
}

\author{
Author(s): Björn Heise , Bernd Bobertz , Cheng Tang , Jan Harff , and Di Zhou
}

Source: Journal of Coastal Research, 66(sp1):34-48. 2013.

Published By: Coastal Education and Research Foundation

DOI: http://dx.doi.org/10.2112/SI_66_4

URL: http://www.bioone.org/doi/full/10.2112/SI 6644

BioOne (www.bioone.org) is a nonprofit, online aggregation of core research in the biological, ecological, and environmental sciences. BioOne provides a sustainable online platform for over 170 journals and books published by nonprofit societies, associations, museums, institutions, and presses.

Your use of this PDF, the BioOne Web site, and all posted and associated content indicates your acceptance of BioOne's Terms of Use, available at www.bioone.org/page/terms_of_use.

Usage of BioOne content is strictly limited to personal, educational, and non-commercial use. Commercial inquiries or rights and permissions requests should be directed to the individual publisher as copyright holder. 


\title{
Surface Sediments of the Pearl River Estuary (South China Sea) - Spatial Distribution of Sedimentological / Geochemical Properties and Environmental Interpretation
}

\author{
Björn Heise ${ }^{\dagger}$, Bernd Bobertz ${ }^{\ddagger}$, Cheng Tang ${ }^{\S}$, Jan Harff ${ }^{\dagger \dagger}$, and Di Zhou \\ ${ }^{\dagger}$ Tennet Offshore GmbH \\ Eisenbahnlängsweg 2 a \\ 31275 Lehrte, Germany \\ bjoern.heise@tennet.eu \\ ${ }^{\ddagger}$ Ernst-Moritz-Arndt-University of Greifswald \\ Institute of Geography and Geology \\ F.-L.-Jahn-Straße 16, 17487 \\ Greifswald, Germany

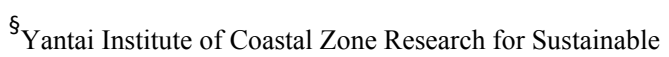 \\ Development, Chinese Academy of Sciences \\ 17 Chunhui Road \\ Laishan District, Yantai, 264003, P.R. China \\ ${ }^{\dagger+}$ University of Szczecin \\ Institute of Marine and Coastal Sciences \\ Leibniz Institute for Baltic Sea Research \\ Seestraße 15, 18119 Warnemünde/ Rostock, Germany \\ www.cerf-jcr.org \\ \# South China Sea Institute of Oceanology \\ Chinese Academy of Sciences \\ 164 West XinGang Road \\ Guangzhou, 510301, P.R. China
}

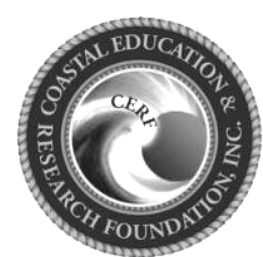

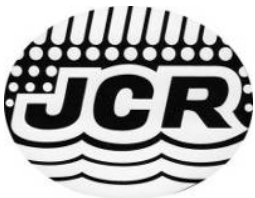

www.JCRonline.org

\begin{abstract}
Heise, B.; Bobertz, B.; Tang, C.; Harff, J., and Zhou, D., 2013. Surface sediments of the Pearl River Estuary (South China Sea) - spatial distribution of sedimentological / geochemical properties and environmental interpretation. In: Harff, J., Leipe, T., Waniek, J.J., and Zhou, D. (eds.), Depositional Environments and Multiple Forcing Factors at the South China Sea's Northern Shelf, Journal of Coastal Research, Special Issue, No. 66, pp. 34-48. Coconut Creek (Florida), ISSN 0749-0208.

The Pearl River Delta (South China) is one of the densest populated regions of the world. This study aims at the investigation and interpretation of the spatial distribution of grain size parameters and geochemical parameters obtained from surface sediment samples. These samples have been taken during cruises in 2003, 2004 and 2005. Investigations of the spatial correlations of the parameters obtained reveal an approximately north-south directed trend for the majority of the parameters. The trend was removed before applying Ordinary Kriging for interpolation. The maps obtained show non-uniform distribution patterns of the sedimentological and geochemical parameters. Here e.g. the concentrations of the $\mathrm{As}, \mathrm{Co}, \mathrm{Cu}, \mathrm{Hg}$ and $\mathrm{Ni}$ decrease to the more marine influenced southeastern parts and show a higher concentration in the central part and at the western shoals of the estuary.
\end{abstract}

ADDITIONAL INDEX WORDS: Sediment composition, trace elements, inorganic parameters, pollution, South China, Pearl River Estuary, LingDingYang Estuary.

\section{INTRODUCTION}

The general target of the study is a more comprehensive understanding of the sedimentary and geochemical situation in the Pearl River Estuary. Thereby, the main focus is on areas under higher anthropogenic influence and sources of anthropogenic impact (heavy metals) onto the estuary.

The work presented in this paper is part of a German-Chinese cooperation involving the IOW (Leibniz-Institute of Baltic Sea Research Institute Warnemünde, Rostock, Germany), SCSIO (South China Sea Institute of Oceanology, Chinese Academy of Science, Guangzhou, P.R. China), GMGS (Guangzhou Marine Geological Survey, Guangzhou, P.R. China) and CCOST (Center for Coastal Ocean Science and Technology, ZhongShan University, Guangzhou, P.R. China). Two projects form the fundament of this work: SEDPERL (Sedimentary facies and environment of the Pearl River Delta, Zhujiang-River, South China Sea) financed by the DFG (German Research Foundation)

DOI:10.2112/SI_66_4 received 12 December 2011; accepted 7 July 2012.

(C) Coastal Education \& Research Foundation 2013 and PECAI (Pearl River Estuary related sediments as response to Holocene climate change and anthropogenic impact) financed by the IB of the BMBF (International Bureau of the Federal Ministry of Education and Research), the MPG (Max Planck Society) and the CAS (Chinese Academy of Science). An overview about the results is given by Harff, Leipe and Zhou (2010) in a Special Issue of the Journal of Marine System. Here, the Pearl River Estuary has been described comprehensively from the sedimentological, geochemical and geophysical point of view including environmental studies and modelling of sediment dynamics. The environmental geochemistry of the last centuries has been studied by Shi et al. (2010) based on geochemical investigations of short sediment cores. A first analysis of the lateral pattern of surface sediment properties including the concentration of geochemical elements was accomplished by Heise, Bobertz and Harff (2010). The authors used multivariate geostatistical methods in order to separate different factors influencing the spatial distribution of surface sediment components. Three main factors (in addition to the hydrographic dynamics within the river mouth system as outlined by Heise et al., 2010) have been identified responsible for the spatial distribution pattern of geochemical elements in 


\section{Pearl River Drainage Basin}

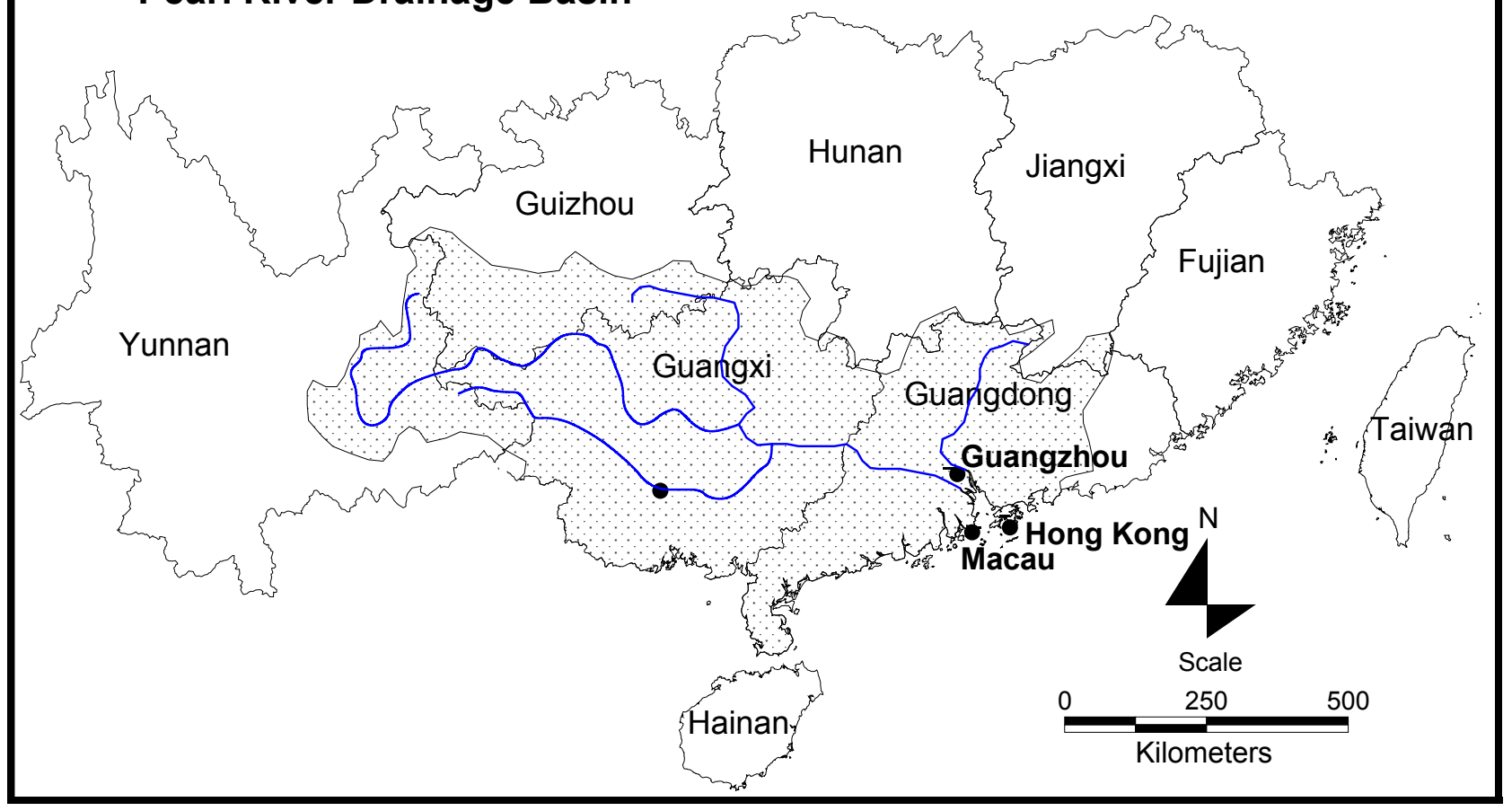

Figure 1. Pearl River Drainage Basin modified from Cao and Wong (2001).

surface sediments of the estuary: anthropogenic effects, inflow of marine water masses form the South China Sea, and the geological structure of the drainage area in the vicinity of the estuary. As focused on factor scores and regionalised classification, these results are presented by Heise, Bobertz and Harff (2010) in a generalised manner. In the present paper, selected heavy metals representing the anthropogenic effects are investigated in order to display the spatial variation of these variables and to interpret it individually.

The main Estuary of the Pearl River is the LingDingYang which is located roughly between Hong Kong, Macau and Guangzhou in the Northwest of the South China Sea (Figure 1). The Pearl River is the third longest river in China (Chen and Heinke, 2001) and the 16th largest river in the world according to the discharge (Wang, Lau and Chan, 2002). Roughly, one eighth of China's population live in the draining area (Figure 1) (Cao and Wong, 2001). Located in the subtropical/tropical zone the area of survey is influenced by the monsoon climate with dry (winter) and wet (summer) seasons.

The work presented in this paper is focused on the LingDingYang Estuary (Figure 2) which is located roughly between Hong Kong, Macau and Guangzhou in the Northwest of the South China Sea (Figure 1).With a length of $70 \mathrm{~km}$ and a width of $4-58 \mathrm{~km}$ the LingDingYang is the largest estuary of the Pearl River (Chen, Zhang and He, 1994) and of South China (Yuan et al., 1994). The average water depth is $4.8 \mathrm{~m}$ (Dong et al., 2004). The LingDingYang Estuary (Figure 2) is divided into the external LingDing in the South and internal LingDing in the North (Lin et al., 1990). The LingDingYang Estuary is shielded to the South by 197 islands including Lema and Lantau Island (Huang, 2000). In the area of survey the seabed is dominated by fine sediments. Only small areas are covered by sand and gravel-sized sediments.

The hydrography of the Pearl River Estuary is ruled by two major factors: tide dominated currents and large river runoff with varying sediment loads. At the Pearl River delta coast a tidal range of $1.0 \mathrm{~m}-3.50 \mathrm{~m}$ exists ( $\mathrm{Wu}, 2002)$.

Generally, wave heights are less than $0.2 \mathrm{~m}$ within the inner estuary (Yan et al., 1994) but during typhoons strong winds can produce wave heights of up to $2.5 \mathrm{~m}$ (Zhao, 1990).

\section{DATA}

65 surface samples were taken with jaw grab during two joint cruises 2004 and 2005 by the IOW and the SCSIO. These cruises were attended by members of the GMGS. The sediment samples were analysed at the IOW. Empirical cumulative weight percentages of sediments from the LingDingYang Estuary obtained by various cruises in the years 2003 and 2004 were accessible from the GMGS. Furthermore, 5 gravity core samples are analysed by the CCOST in 2004. The sample stations are displayed in Figure 3. 


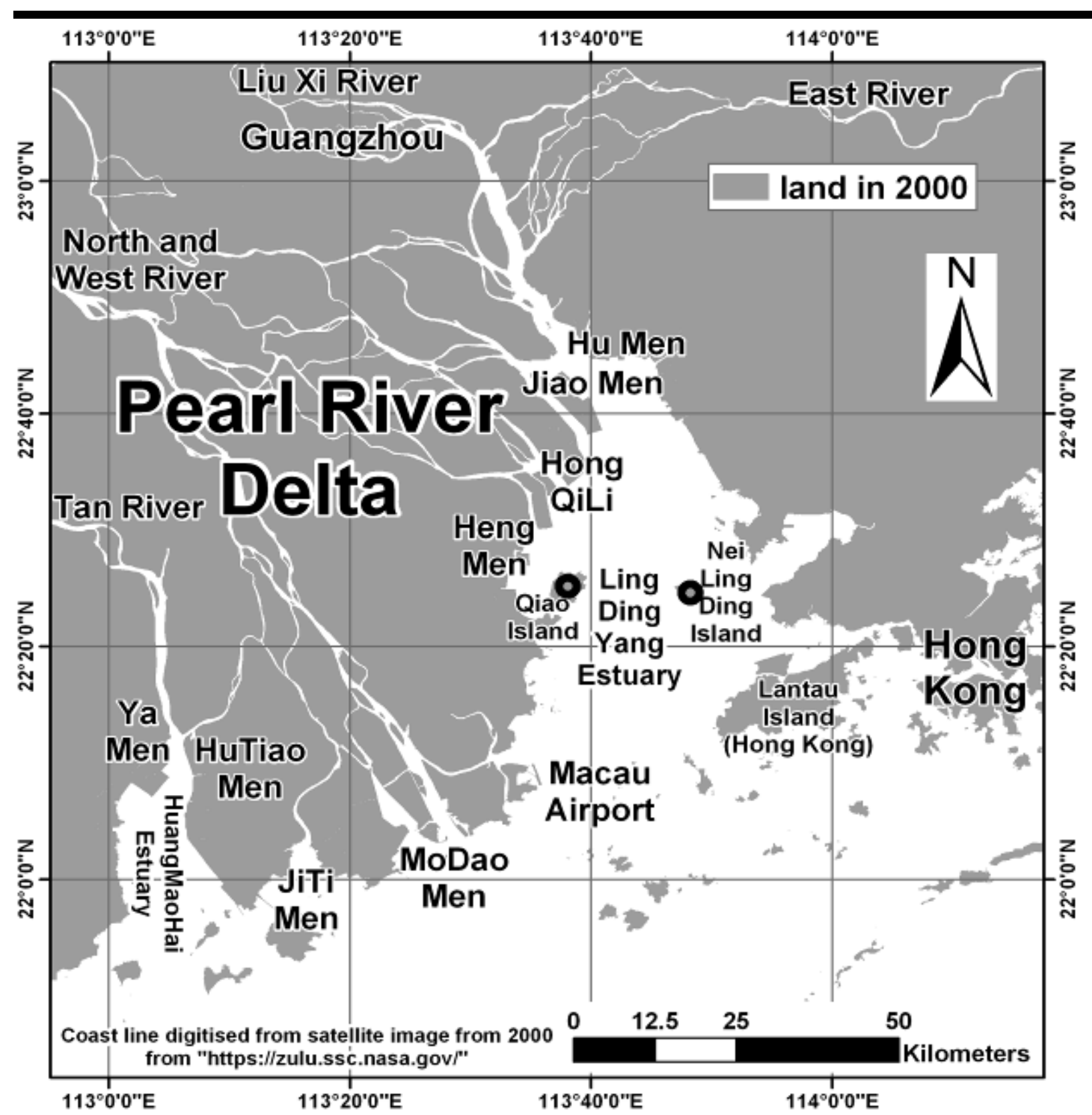

Figure 2. Pearl River delta and estuary.

\section{Grain Size Data}

The sediment data have been compiled from different sources. The grain size data from the GMGS were measured with the Malvern Mastersizer 2000 (see http://www.malvern.com). The CCOST measured the grain sizes with the Cilas 940L Lasersizer. The grain sizes analysed by the IOW were obtained with the Lasersizer Cilas 1180L (http://www.cilas.com/particlesize-analyzer.htm).
All granulometrical parameters determined at the sediment samples taken 2003 to 2005 will be referred further on as composite data set.

Data from different sources are usually obtained applying different measurement standards. These different data sets in different grain size sequences combined can cause problems which are discussed throughout the literature (Aitchison, 1986; Aitchison et al., 2000; Bohling et al., 1998; Tauber, 1997; Tauber, 1999; Tauber, 2002; Tauber and Emeis, 2005). To solve 


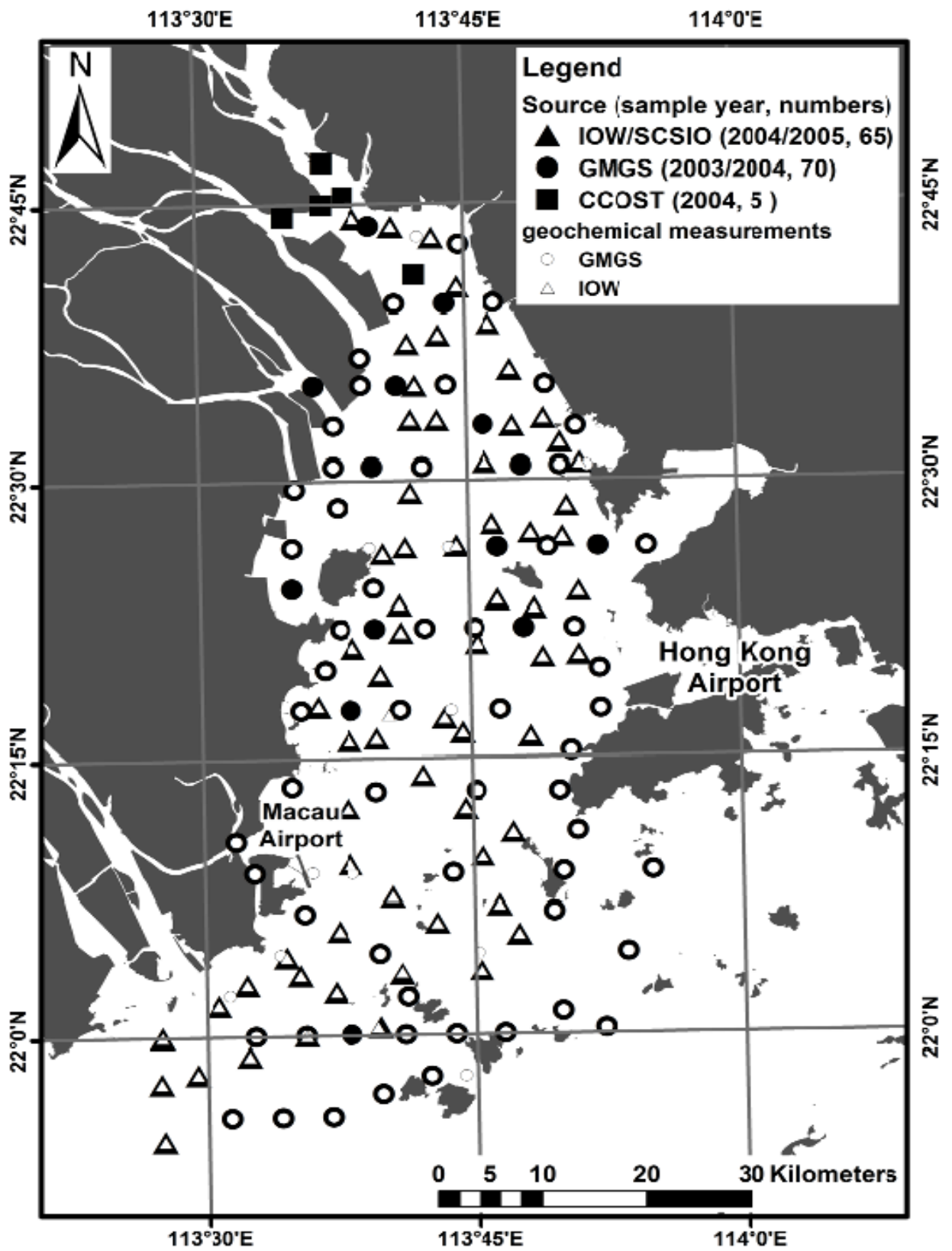

Figure 3. Regional distribution of stations from different measuring campaigns used in this study.

this problems Tauber (1995) presented a Fermi like function (equation 1) with the parameters 'median' and 'sorting'. This symmetrical function approximates the empirical cumulative grain-size distribution.

To express the skewness of a grain size distribution Bobertz (2000) extended the Tauber (1995) equation (see equation 2). As Bobertz and Harff (2004) state this skewness parameter is different to the ones normally found in the literature because it is independent from the sorting. Furthermore, median and sorting (just for low absolute values of skewness) are comparable to the parameters of the method of Folk and Ward (1957) (Bobertz and Harff, 2004).

Both models were used: the one of Tauber (1995) as a symmetrical model with two fitting parameters and the model of Bobertz (2000) as asymmetrical model with three fitting parameters: 


$$
F(x)=\frac{1}{1+e^{-1.7 \frac{x-m e d}{s o}}}
$$

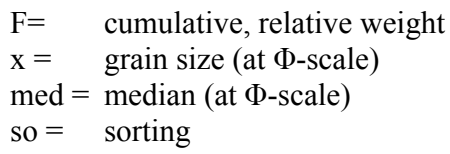

$$
F(x)= \begin{cases}\left(1+e^{\left.-1.7 \frac{x-m e d}{s o-s k \cdot \tanh (x-m e d)}\right)^{-1}},\right. & s o>s k \cdot \tanh (z) \vee s k=0 \\ 1 & , \quad s o \leq s k \cdot \tanh (z) \wedge s k>0 \\ 0 & , \quad s o \leq s k \cdot \tanh (z) \wedge s k<0\end{cases}
$$

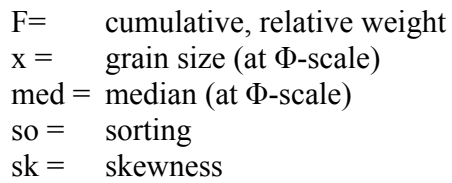

The calculations were accomplished using an unpublished software by Bobertz (2000). However, the parameter fitting can be done by any statistical software which consists of modules for least square fitting. To decide which distribution model is the optimal one for a given grain size sample the corrected Akaike Information Criterion (AICc) was calculated (Hurvich, 1989). The AICc relates the mean quadratic differences between the data points and points calculated by a model function with the number of parameters of the model. The smaller the AICc the better a model is suited for the description of a given data set. For grain size records the AICc's from both model fittings were compared and the values of the two parameters median and sorting of the best suited model are used for the grain size characterisation. More details about the method used and the AICc can be found in Bobertz (2000).

\section{Inorganic Geochemistry}

With the IOW/SCSIO and GMGS there have been two different sources of geochemical measurements. All stations where geochemical properties are available are shown in Figure 3.

Table 1 shows the geochemical inventory of those variables analysed in this study itemised into elements (As, Ba, Cd, Co, $\mathrm{Cr}, \mathrm{Cu}, \mathrm{Ga}, \mathrm{Hg}, \mathrm{Ni}, \mathrm{Pb}, \mathrm{Sr}, \mathrm{Zn}$ ) and analysing institutions.

The following descriptions of the treatments and measurements of the geochemical parameters are just valid for the IOW-samples. Due to the lack of information about the treatments and measurements of the GMGS-samples a two sided Kolmogorov-Smirnov-Test on a significance level 0.05 was applied and confirm that the different data sets are from one population. Therefore, the data from the IOW/SCSIO and the GMGS data sets can be merged and analysed together.

The elements $\mathrm{Co}, \mathrm{Cr}, \mathrm{Cu}, \mathrm{Pb}$ and $\mathrm{Zn}$ were obtained by an Inductively Coupled Plasma Atomic Emission Spectrometry (ICP-AES) at the IOW, Rostock.
The elements $\mathrm{Ba}, \mathrm{Ga}, \mathrm{Ni}, \mathrm{Sr}$ and $\mathrm{Zr}$ were determined using the X-ray fluorescence spectrometry PW 2404 from Philips.

$\mathrm{Hg}$ has been analysed via the System DMA-80 (Direct Mercury Analyzer) from the company MLS GmbH and As and $\mathrm{Cd}$ with the atomic absorption spectrometer Analyst 800 from PERKIN ELMER.

Table 1. Quantity of geochemical measurements from IOW/SCSIO and GMGS.

\begin{tabular}{cll}
\hline \hline Element group & ID of data set & Number \\
\hline & GMGS & 52 \\
$\mathrm{Hg}, \mathrm{As}, \mathrm{Cd}$ & IOW/SCSIO & 66 \\
& Total & 118 \\
& GMGS & 66 \\
$\mathrm{Co}, \mathrm{Cu}, \mathrm{Ni}, \mathrm{Pb}, \mathrm{Cr}, \mathrm{Sr}, \mathrm{Zn}, \mathrm{Zr}, \mathrm{Ba}, \mathrm{Ga}$ & IOW/SCSIO & 66 \\
& Total & 132 \\
\hline
\end{tabular}

To determine As and Cd parts of the prepared samples for the ICP-AES Spectrometry analysis were taken.

The quality of the measurements for the ICP-AES and X-ray fluorescence spectrometry were ensured by the certified sediment standards ABSS and MBSS. Thereby, all measurements were inside the range of the quality controls.

\section{Standardisation of Geochemical Parameters}

Geochemical parameters, especially metals, are mainly bound to fine, mainly clay minerals. To erase dilution effects through other components and to determine the relative non-natural accumulation of the elements, the geochemical parameters are standardised by aluminium, iron, organic carbon or one of their compounds.

The standardisation of selected elements has been done based on the IOW/SCSIO data set. In this paper the values of the geochemical parameters $\mathrm{Hg}, \mathrm{Ni}$, Co and $\mathrm{Pb}$ have been standardised by $\mathrm{Al}_{2} \mathrm{O}_{3}$ at each sample station. Afterwards, these values have been interpolated. Regions outside the sample area were blanked out in order to avoid extrapolation effects.

\section{DATA EXPLORATION}

The data analysed here are to be regarded a subset of a larger set of research data which has been studied in a precedent investigation using multivariate statistical exploration techniques (Heise, Bobertz and Harff, 2010). The whole set of variables is shown by the lines in Table 3. Principle Component Analysis (PCA) has been applied to reveal correlation between the variables and to reduce the multidimensional datasets to a few synthetic variables (element group identification) called factors (or principle components). In the results three factors have been extracted comprising $75 \%$ of the total variance of the multivariate data set. By high loadings of heavy metals, the first factor ( $53 \%$ of the total variance) expresses the anthropogenic 
effect in sediment accumulation. The second factor (12\%) expresses through high loadings of $\mathrm{Ca}, \mathrm{Sr}$ and total inorganic carbon (TIC) the marine influence of sediment accumulation and the third factor $(11 \%$ of the total variance) stands with dominating $\mathrm{Rb}$ and $\mathrm{K}_{2} \mathrm{O}$ for erosion products from granites outcropping in the surrounding area of the Pearl River delta (Heise, Bobertz and Harff, 2010). Using the scores of the three factors as independent (non-correlated) variables a cluster analysis has been carried out for the sampling sites in the Pearl River Estuary. A partition of 4 classes within the hierarchical dendrogram structure was selected based on the mean statistical entropy.

Using the primary data the means and standard deviations for each of the sediment classes have been estimated using standard statistical methods. The results are given in Table 3 .

Heise, Bobertz and Harff (2010) showed that the four classes reflect areas where different parameters are dominating the sediment. Class 1 comprise mainly coarser sediments, while class 2 stands for sediments dominated by deposits eroded from granites of the northeastern catchment area of the estuary. Class 3 , situated in the most southern part of the outer LingDingYang Estuary represents the influence of the marine environment. Class 4 extending to the West up to the LingDingYang Channel is characterised by fines deposited in an environment with high sedimentation rates.

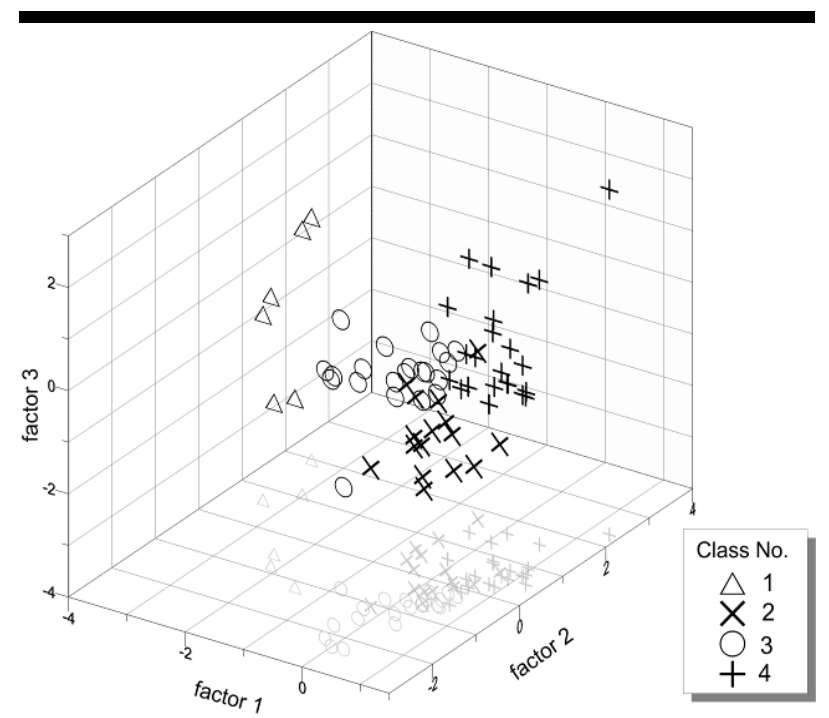

Figure 4. 3D plot of samples represented by factor scores. The class allocation of each sample is marked by a symbol. Light grey symbols in the factor-1-2-plane emulate 'shadows' to support readability of the diagram.

Relative high values of $\mathrm{Rb}$ and $\mathrm{TiO}_{2}$ point to terrestrial origin of the deposits. Metals like $\mathrm{Co}, \mathrm{Cr}, \mathrm{Cu}, \mathrm{Ni}, \mathrm{Pb}, \mathrm{Hg}, \mathrm{Cd}$ and $\mathrm{As}$ as well as for the nutrient elements of $\mathrm{P}_{2} \mathrm{O}_{5}$ and $\mathrm{N}$ show the relive highest concentrations in this class. Therefore, it is assumed that the anthropogenic input into this area is high.
In order to study the spatial distribution pattern of typical anthropogenically influenced variables in detail the following variables have been selected: Median $(\mu \mathrm{m})$, sorting, $\mathrm{Al}_{2} \mathrm{O}_{3}(\%)$, $\mathrm{Co}(\mathrm{mg} / \mathrm{kg}), \mathrm{Cu}(\mathrm{mg} / \mathrm{kg}), \mathrm{Ni}(\mathrm{mg} / \mathrm{kg}), \mathrm{Pb}(\mathrm{mg} / \mathrm{kg}), \mathrm{Hg}(\mu \mathrm{g} / \mathrm{kg})$, As $(\mathrm{mg} / \mathrm{kg})$.

The spatial distributions have been mapped within the area of investigation using Kriging as the geostatistical interpolation method.

\section{INTERPOLATION METHOD}

The software Surfer for Windows has been used (Surfer ${ }^{\circledR}$, 2004) to interpolate and manipulate the data.

Interpolations were done with the gridding method Ordinary Kriging (Journel and Huijbregts, 1978). Ordinary Kriging is one out of a group of geostatistical interpolation methods based on stochastics. All (point) Kriging methods are exact interpolators, what means the method honours the data in any case (Olea, 1999). Fundament of Ordinary Kriging is the estimation of the spatial autocorrelation function from the empirical semivariogram (Deutsch and Journel, 1992).

Since the empirical semivariogram derived from the data used often reveals an underlying trend, it was necessary to remove this trend for estimation of the autocorrelation function. The method of directional semivariogram analysis was chosen to obtain the trend, free empirical semivariogram and model fitting.

All maps of parameters were blanked using the Kriging Variance to avoid extrapolation effects in regions with no data.

Before interpolations were done, all positions of sample stations were projected to UTM49N on WGS84 resulting in a nearly homogenous map space where distances are almost direction independent (what is not the case using geographical coordinates like decimal degrees on WGS84). Such projection is necessary for all distance weighted algorithms. WGS84 was used for all figures in the introduction and data chapters where no data have been interpolated.

\section{RESULTS}

\section{Spatial Distribution of Grain Size Parameters}

The spatial distribution of different parameters of the surface sediments has been displayed in maps. These parameters are median and sorting determined by the formula given in equation 1 and 2 (Figure 5). The parameters from the composite data set have been interpolated using Ordinary Kriging and blanked via the Kriging Variance.

Therefore, all interpolated values have been evaluated for their quality and are assumed to be reasonably accurate in their displayed extent.

The median of the grain size distribution falls commonly into the silt or clay fraction (dark grey areas in Figure 5). Very fine sediments are located in the centre of the estuary and at the western shoals north of Macau until Qiao Island where no large outlets of the river are present. Sediments with a median in the fine sand fraction are found in the North of the LingDingYang Estuary, west of Shenzhen and South of Lantau Island (Hong Kong Airport). Almost all sediment samples show a poor sorting (Figure 5). 
Table 2. Mean and standard deviation of chemical elements and sediment parameters for each of the 4 classes (given by the class centroids) after Heise, Bobertz and Harff (2010). The variables used for the present study are marked by grey shadows.

\begin{tabular}{|c|c|c|c|c|c|c|c|c|}
\hline \multirow[b]{2}{*}{$\begin{array}{l}\text { parameter } \\
\text { (unit) }\end{array}$} & \multicolumn{2}{|l|}{ Class 1} & \multicolumn{2}{|l|}{ Class 2} & \multicolumn{2}{|l|}{ Class 3} & \multicolumn{2}{|l|}{ Class 4} \\
\hline & Mean & $\begin{array}{c}\text { Std. } \\
\text { Deviation }\end{array}$ & Mean & $\begin{array}{c}\text { Std. } \\
\text { Deviation }\end{array}$ & Mean & $\begin{array}{c}\text { Std. } \\
\text { Deviation }\end{array}$ & Mean & $\begin{array}{c}\text { Std. } \\
\text { Deviation }\end{array}$ \\
\hline $\mathrm{N}(\%)$ & 0.03 & 0.02 & 0.09 & 0.03 & 0.08 & 0.02 & 0.11 & 0.03 \\
\hline TS (\%) & 0.35 & 0.37 & 0.35 & 0.07 & 0.25 & 0.11 & 0.20 & 0.05 \\
\hline TIC (\%) & 0.16 & 0.09 & 0.14 & 0.04 & 0.28 & 0.05 & 0.20 & 0.05 \\
\hline TOC $(\%)$ & 0.36 & 0.31 & 0.93 & 0.13 & 0.97 & 0.09 & 1.15 & 0.14 \\
\hline ignition loss (\%) & 4.1 & 1.5 & 7.8 & 1.0 & 8.1 & 0.8 & 8.4 & 1.1 \\
\hline water content (\%) & 24.1 & 5.7 & 38.7 & 3.4 & 38.9 & 2.8 & 39.7 & 4.1 \\
\hline Median $(\mu \mathrm{m})$ & 148 & 167 & 7 & 2 & 8 & 3 & 7 & 3 \\
\hline Silt + clay content $(\%)$ & 48 & 23 & 96 & 4 & 98 & 4 & 97 & 5 \\
\hline sorting & 2.9 & 0.3 & 2.1 & 0.3 & 2.0 & 0.2 & 2.0 & 0.3 \\
\hline $\mathrm{SiO}_{2}(\%)$ & 73.4 & 5.7 & 58.5 & 3.9 & 57.2 & 2.4 & 56.1 & 3.5 \\
\hline $\mathrm{TiO}_{2}(\%)$ & 0.60 & 0.15 & 0.90 & 0.08 & 1.07 & 0.08 & 1.12 & 0.09 \\
\hline $\mathrm{Al}_{2} \mathrm{O}_{3}(\%)$ & 10.9 & 2.8 & 18.3 & 1.8 & 17.0 & 1.3 & 18.3 & 1.6 \\
\hline $\mathrm{Fe}_{2} \mathrm{O}_{3}(\%)$ & 4.4 & 1.2 & 6.6 & 0.5 & 6.9 & 0.4 & 7.5 & 0.5 \\
\hline $\mathrm{MnO}(\%)$ & 0.08 & 0.063 & 0.088 & 0.012 & 0.109 & 0.017 & 0.133 & 0.025 \\
\hline $\mathrm{MgO}(\%)$ & 0.84 & 0.42 & 1.41 & 0.17 & 1.71 & 0.10 & 1.58 & 0.14 \\
\hline $\mathrm{CaO}(\%)$ & 0.62 & 0.47 & 0.58 & 0.16 & 1.26 & 0.20 & 0.94 & 0.20 \\
\hline $\mathrm{Na}_{2} \mathrm{O}(\%)$ & 0.46 & 0.28 & 0.96 & 0.29 & 1.40 & 0.26 & 0.90 & 0.25 \\
\hline $\mathrm{K}_{2} \mathrm{O}(\%)$ & 2.04 & 0.49 & 2.64 & 0.15 & 2.47 & 0.11 & 2.50 & 0.15 \\
\hline $\mathrm{P}_{2} \mathrm{O}_{5}(\%)$ & 0.075 & 0.029 & 0.156 & 0.014 & 0.160 & 0.013 & 0.189 & 0.011 \\
\hline $\mathrm{Ba}(\mathrm{mg} / \mathrm{kg})$ & 253 & 64 & 341 & 25 & 346 & 33 & 373 & 33 \\
\hline Co $(\mathrm{mg} / \mathrm{kg})$ & 9.85 & 3.02 & 17.74 & 2.00 & 19.05 & 1.91 & 20.92 & 2.00 \\
\hline $\mathrm{Cr}(\mathrm{mg} / \mathrm{kg})$ & 41.0 & 13.5 & 78.2 & 8.8 & 80.9 & 6.9 & 95.5 & 8.3 \\
\hline $\mathrm{Cu}(\mathrm{mg} / \mathrm{kg})$ & 21.0 & 8.2 & 57.2 & 15.2 & 52.5 & 8.7 & 72.1 & 18.5 \\
\hline $\mathrm{Ga}(\mathrm{mg} / \mathrm{kg})$ & 11.6 & 3.5 & 22.3 & 2.5 & 20.1 & 2.0 & 22.4 & 2.3 \\
\hline $\mathrm{Li}(\mathrm{mg} / \mathrm{kg})$ & 33.4 & 21.2 & 67.5 & 12.5 & 67.4 & 6.9 & 62.4 & 13.7 \\
\hline $\mathrm{Ni}(\mathrm{mg} / \mathrm{kg})$ & 25.6 & 9.0 & 40.3 & 5.5 & 43.1 & 4.8 & 50.2 & 5.4 \\
\hline $\mathrm{Pb}(\mathrm{mg} / \mathrm{kg})$ & 37.6 & 7.9 & 66.3 & 7.3 & 56.9 & 7.8 & 69.6 & 6.9 \\
\hline $\mathrm{Rb}(\mathrm{mg} / \mathrm{kg})$ & 111.3 & 21.9 & 159.1 & 10.2 & 134.8 & 10.5 & 140.3 & 11.8 \\
\hline $\mathrm{Sr}(\mathrm{mg} / \mathrm{kg})$ & 47.9 & 22.8 & 65.7 & 7.1 & 83.4 & 7.5 & 75.9 & 4.9 \\
\hline $\mathrm{Zn}(\mathrm{mg} / \mathrm{kg})$ & 64.8 & 20.9 & 146.5 & 24.3 & 146.2 & 24.3 & 194.0 & 23.3 \\
\hline $\mathrm{Zr}(\mathrm{mg} / \mathrm{kg})$ & 257.3 & 57.7 & 272.5 & 69.9 & 224.7 & 15.4 & 233.2 & 46.8 \\
\hline $\mathrm{Hg}(\mu \mathrm{g} / \mathrm{kg})$ & 48.5 & 23.0 & 162.6 & 38.4 & 151.8 & 31.8 & 218.4 & 47.3 \\
\hline $\mathrm{Cd}(\mathrm{mg} / \mathrm{kg})$ & 0.20 & 0.17 & 0.48 & 0.31 & 0.40 & 0.21 & 1.23 & 0.97 \\
\hline As $(\mathrm{mg} / \mathrm{kg})$ & 17.6 & 2.1 & 32.2 & 3.2 & 32.5 & 4.6 & 37.9 & 4.9 \\
\hline
\end{tabular}

The distribution patterns of the sorting do not correspond to the ones of the grain size median. For clastic sediments with a median of fine sand a better sorting than for sediments of the silt/clay fraction was expected due to sorting effects on hydrographically transported clastica along a current influenced sea/river bed. But, for instance, in the North of the LingDingYang Estuary, there are sediments with a median of fine sand or fine silt with the same poor sorting. Consequently, it is assumed that these sediments are not recently deposited by the river.

\section{Spatial Distribution of Geochemical Parameters (IOW/SCSIO and GMGS Data Sets)}

The univariate statistics for the geochemical parameters measured for the IOW/SCSIO and GMGS group are shown in Table 2. The elements $\mathrm{Co}$ and $\mathrm{Ni}$ show extremely high concentrations in comparison to the second largest value. These high values occur for $\mathrm{Ni}$ and $\mathrm{Co}$ at the same station so it can be assumed that these values do not refer to analytical mistakes. More likely, they are indicators for highly polluted sediments.
The following maps (Figure 6 to 9) present the distribution of six geochemical parameters. On one hand, these geochemical parameters show some general similarities in their distribution. All element concentrations decrease to the southeastern part of the estuary, an area with more marine influence. On the other hand, in detail, the spatial element distributions differ from each other as shown in the following.

For $\mathrm{Hg}$ (Figure 6) the highest concentrations are found east and south of Macau Airport and south of MoDaoMen. Additionally, in the central part of the estuary there are some areas with higher concentrations of $\mathrm{Hg}$ than within the rest of the estuary. This suggests that an input of $\mathrm{Hg}$ into the coastal zone and Pearl River Estuary takes place through the outlet MoDaoMen and from the offshore area around Macau.

The element As (Figure 6) shows relatively high concentrations in the central part of the estuary and south of MoDaoMen. In opposite the total As concentration in the North and the East-Southeast is relatively low. Thereby, the relatively lower concentrations in the North part of the estuary are assumed to be that low due to the coarser sediments in this area which do not bound As as much as the clay minerals. 

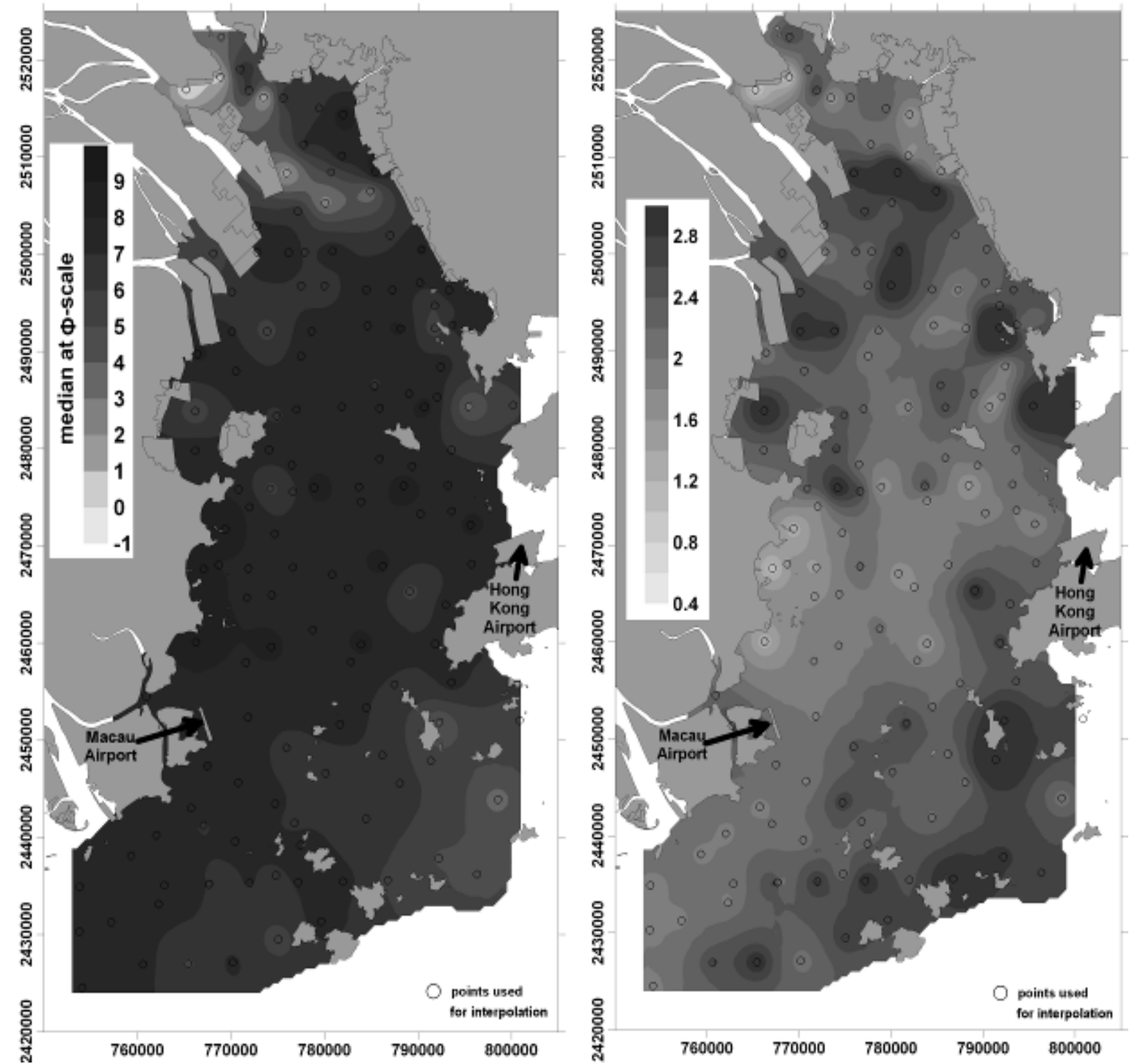

Figure 5. Grain size median (left) and grain size sorting (right) according to equation 1 and 2 based on a composite data set.

Accordingly, it is assumed that the input of As into the estuary is around the same at all outlets.

The concentrations of the chalcophile element $\mathrm{Cu}$ (Figure 6) are low in the southeastern part of the estuary and in some areas in the northern part of the LingDingYang Estuary where mainly coarser sediments can be found. In natural environments $\mathrm{Cu}$ acts as a rock-forming element but exists as well as an independent mineral (Wang et al., 2008). Therefore, the $\mathrm{Cu}$ input should be fluvial. The overall distribution patterns represent the hydrodynamic characteristics of the estuary. The total concentrations of $\mathrm{Cu}$ are higher on the western shoals due to the main water outflow out of the estuary along this way.

The total concentrations of Ni (Figure 6) are high at a hot spot in the North of the LingDingYang Estuary and in a larger extent north of Macau Airport. A location with high total concentration of $\mathrm{Ni}$ exists in the northeastern part. It is assumed that there is an area with higher input of pollutants probably originating from the industrial parts of the DongGuan city. This higher value occurs as well for the element $\mathrm{Cu}$ (Figure 6). In opposition, in the northern part of the estuary as well as in the southeastern part and west off Lantau Island, there are larger areas with relatively low Ni concentrations. It is supposed that the Ni input comes from the ZhuHai area and via sediment transport from JiaoMen. This corresponds with the siderophile characteristics of $\mathrm{Ni}$ and its indication for chemical weathering of rock formations. This hints for a terrestrial input into the LingDingYang Estuary. 
Co (Figure 7) as a siderophile element shows the highest concentrations in the central, central western and southwestern part of the estuary, where no main outlets are present. Lower concentrations are to be found in the northern and southeastern part. Co reflects the distribution patterns of the sediments. Each area dominated by fines shows a high concentration of Co. In opposite, the Co concentration is relatively low in areas with coarser sediments. This is the case in the northern, middle eastern and south eastern part of the LingDingYang Estuary. Therefore, Co shows a stronger connection to the grain size of the sediment than $\mathrm{Cu}$ and Ni. Furthermore, $\mathrm{Co}$ is an indicator for chemical weathering of rocks and shows higher concentrations in the fine sediments located close to the outlets and at the sediment transport pathways.

For $\mathrm{Pb}$ (Figure 7), this "cobalt distribution patterns" (explained before) are even more obvious. $\mathrm{Pb}$ shows low concentrations in front of the four main outlets of the LingDingYang Estuary and southeast of the survey area.

The only outlet covered by the maps which shows a higher concentration at its mouth is MoDaoMen, outside of the LingDingYang Estuary.

Additionally, there are spots with relatively high concentrations of $\mathrm{Pb}$ in the rest of the Estuary. The reason for this could be that $\mathrm{Pb}$ is mainly brought into the sediment by the atmosphere (industrial waste air) rather than by river discharge. After the input, the $\mathrm{Pb}$ immediately gets bound to the fines.

\section{Standardised Geochemical Parameters}

The distribution of the standardised $\mathrm{Hg}$ by $\mathrm{Al}_{2} \mathrm{O}_{3}$ (Figure 8) reflects strongly the bathymetry in the middle and southern part of the LingDingYang Estuary and in the northern parts it mirrors the sediment types. These patterns do not occur on the display of the total concentration of $\mathrm{Hg}$ in the sediment (Figure 6). Consequently, it is assumed that the $\mathrm{Hg}$, which is connected to the fines, is stronger accumulated in the central part of the estuary, the LingDingYang Channel, because of the stronger currents there. Furthermore, there is no specific anthropogenic impact in the areas with coarser sediments.

The standardised $\mathrm{Ni}$ by $\mathrm{Al}_{2} \mathrm{O}_{3}$ (Figure 8) shows in the southern, western, eastern and central part of the LingDingYang Estuary similar pattern to its total concentration (Figure 6). The northern central parts covered with fine sand show high values of standardised Ni. That means that the pollution there is higher than elsewhere. Therefore, it is assumed that there must be a local source for the input of pollutants probably due to dumping of sediment from dredging which takes heavily place in this area. These dredging activities could be seen during the cruises 2004 and 2005.

The distribution patterns of the standardised $\mathrm{Co}$ by $\mathrm{Al}_{2} \mathrm{O}_{3}$ (Figure 8) do not coincide with the patterns of the total concentration of Co (Figure 7). For the standardised Co there are higher values in the central southern, the southern west and western part. Consequently, it can be concluded that in these parts the relative pollution is higher than e.g. at the wide spread areas on the eastern shoals where relatively low values of the standardised Co can be found. A possible reason for this could be the distribution of Co via the hydrodynamic patterns in the LingDingYang Estuary. Thereby, the main water outflow is via the west shoals.

The distribution of the standardised $\mathrm{Pb}$ by $\mathrm{Al}_{2} \mathrm{O}_{3}$ (Figure 8 ) is not similar to the total concentration of $\mathrm{Pb}$ (Figure 7). There are higher values in the northern parts and south of MoDaoMen (southwestern part). The values decrease into the direction of the open sea. In general, it can be assumed that the anthropogenic input due to the areal input of $\mathrm{Pb}$ is relatively similar all over the estuary.

The aluminium oxide concentration (Figure 9) which has been used to standardise the elements $\mathrm{Hg}, \mathrm{Ni}, \mathrm{Co}$ and $\mathrm{Pb}$ is quite equally distributed.

There is just one point with lower concentrations of $\mathrm{Al}_{2} \mathrm{O}_{3}$ in the North of the estuary. Here the relative concentrations of $\mathrm{Ni}$ and $\mathrm{Pb}$ show larger values. A reason for this could be the fine sand in this area.

\section{DISCUSSION}

In the following the results are discussed and compared to the literature about geochemical parameters in the LingDingYang Estuary.

The results of Chen et al. (2006) - who analysed five sites in the Pearl River estuary - and Liu et al. (2003) show that the youngest sediments in the Pearl River Estuary especially at the western shallows have a higher content of heavy metals. This coincides with the results of this paper, that bases on a larger number of analysed sites (66 from the PECAIProject $=$ IOW/SCSIO data set plus up to 66 from the GMGS).

Table 3. Geochemical parameters: contents of chemical elements. The outlier free arithmetic mean was calculated without the five lowest and five highest values (low $\left(2^{\text {nd }}\right)=2^{\text {nd }}$ lowest value, high $\left(2^{\text {nd }}\right)=2^{\text {nd }}$ highest value, o.f.a.m. $=$ outlier free arithmetic mean)

\begin{tabular}{|c|c|c|c|c|c|c|c|c|c|c|c|c|c|}
\hline & $\begin{array}{c}\mathrm{Co} \\
\mathrm{mg} / \mathrm{kg}\end{array}$ & $\begin{array}{c}\mathrm{Cu} \\
\mathrm{mg} / \mathrm{kg}\end{array}$ & $\begin{array}{c}\mathrm{Ni} \\
\mathrm{mg} / \mathrm{kg}\end{array}$ & $\begin{array}{c}\mathrm{Pb} \\
\mathrm{mg} / \mathrm{kg}\end{array}$ & $\begin{array}{c}\mathrm{Cr} \\
\mathrm{mg} / \mathrm{kg}\end{array}$ & $\begin{array}{c}\mathrm{Sr} \\
\mathrm{mg} / \mathrm{kg}\end{array}$ & $\begin{array}{c}\mathrm{Zn} \\
\mathrm{mg} / \mathrm{kg}\end{array}$ & $\begin{array}{c}\mathrm{Zr} \\
\mathrm{mg} / \mathrm{kg}\end{array}$ & $\begin{array}{c}\mathrm{Ba} \\
\mathrm{mg} / \mathrm{kg}\end{array}$ & $\begin{array}{c}\mathrm{Ga} \\
\mathrm{mg} / \mathrm{kg}\end{array}$ & $\begin{array}{c}\mathrm{As} \\
\mathrm{mg} / \mathrm{kg}\end{array}$ & $\begin{array}{c}\mathrm{Hg} \\
\mathrm{mg} / \mathrm{kg}\end{array}$ & $\begin{array}{c}\mathrm{Cd} \\
\mathrm{mg} / \mathrm{kg}\end{array}$ \\
\hline minimum & 5.0 & 8.8 & 11.6 & 9.9 & 16.0 & 23.2 & 27.2 & 30.8 & 111.0 & 6.0 & 5.5 & 0.014 & 0.010 \\
\hline low $\left(2^{\text {nd }}\right)$ & 6.7 & 10.0 & 13.0 & 15.9 & 40.0 & 30.4 & 28.2 & 49.0 & 136.0 & 6.1 & 11.2 & 0.021 & 0.030 \\
\hline $\operatorname{high}\left(2^{\text {nd }}\right)$ & 32.4 & 155.0 & 64.4 & 86.7 & 132.0 & 291.0 & 237.0 & 411.0 & 505.0 & 31.4 & 49.8 & 0.369 & 3.040 \\
\hline maximum & 32.7 & 779.0 & 181.0 & 116.0 & 179.0 & 434.0 & 260.0 & 429.3 & 569.0 & 32.4 & 52.9 & 0.380 & 5.390 \\
\hline $\begin{array}{l}\text { arithmetic } \\
\text { mean }\end{array}$ & 19.4 & 57.2 & 40.5 & 51.7 & 80.6 & 93.2 & 135.2 & 186.5 & 344.9 & 21.0 & 28.4 & 0.168 & 0.560 \\
\hline o.f.a.m. & 19.4 & 51.1 & 39.7 & 51.8 & 80.2 & 87.5 & 135.1 & 183.8 & 346.1 & 21.2 & 28.3 & 0.166 & 0.487 \\
\hline median & 19.2 & 52.0 & 40.0 & 54.8 & 83.0 & 82.3 & 134.0 & 187.2 & 355.0 & 21.6 & 30.0 & 0.166 & 0.350 \\
\hline $\begin{array}{l}\text { standard } \\
\text { deviation }\end{array}$ & 5.0 & 67.4 & 16.2 & 17.9 & 21.3 & 47.2 & 49.6 & 71.8 & 81.9 & 5.2 & 9.0 & 0.065 & 0.646 \\
\hline
\end{tabular}



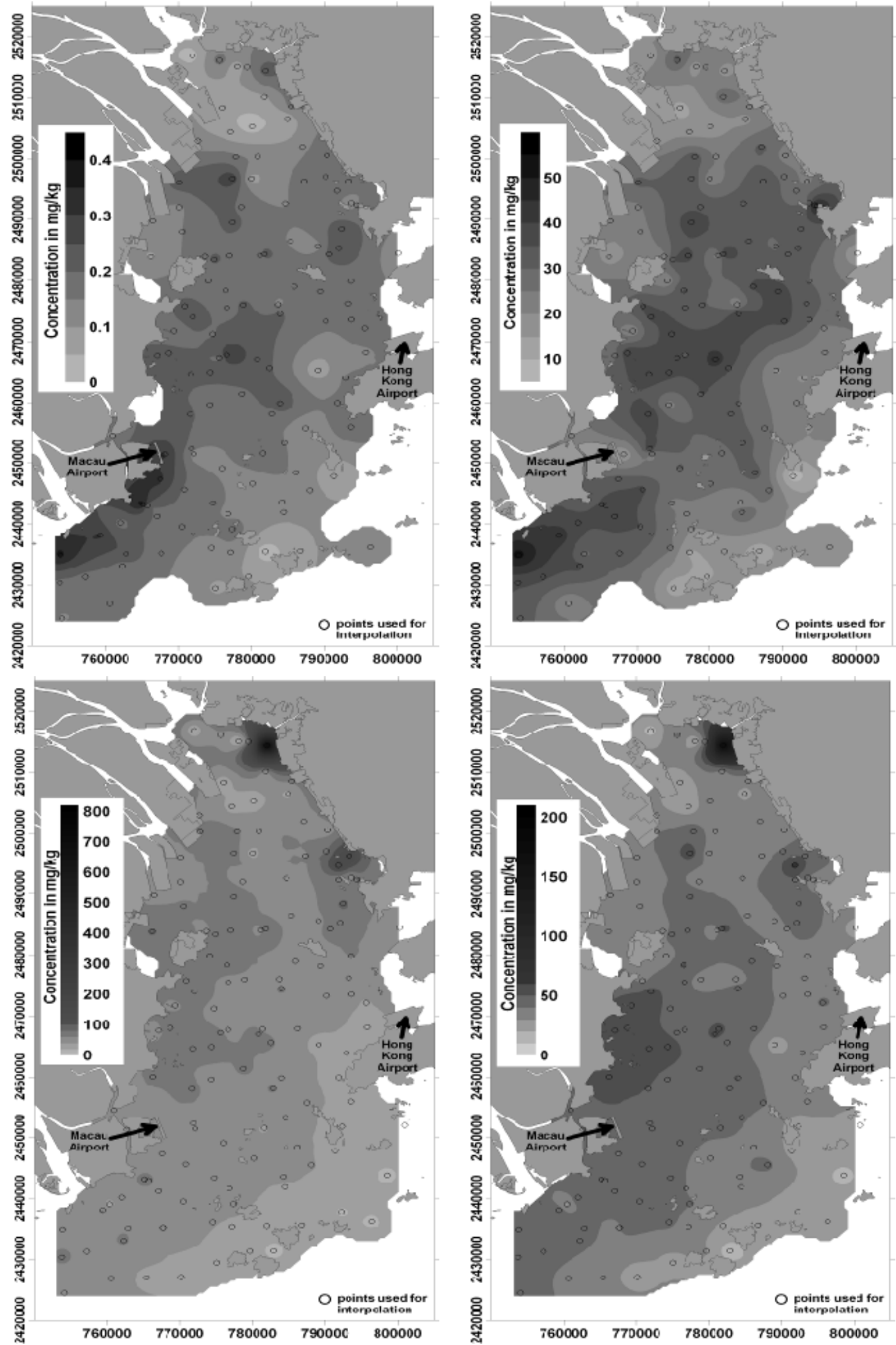

Figure 6. The distribution of $\mathrm{Hg}$, As (upper panel) and $\mathrm{Cu}, \mathrm{Ni}$ (lower panel) based on the composite data set. 

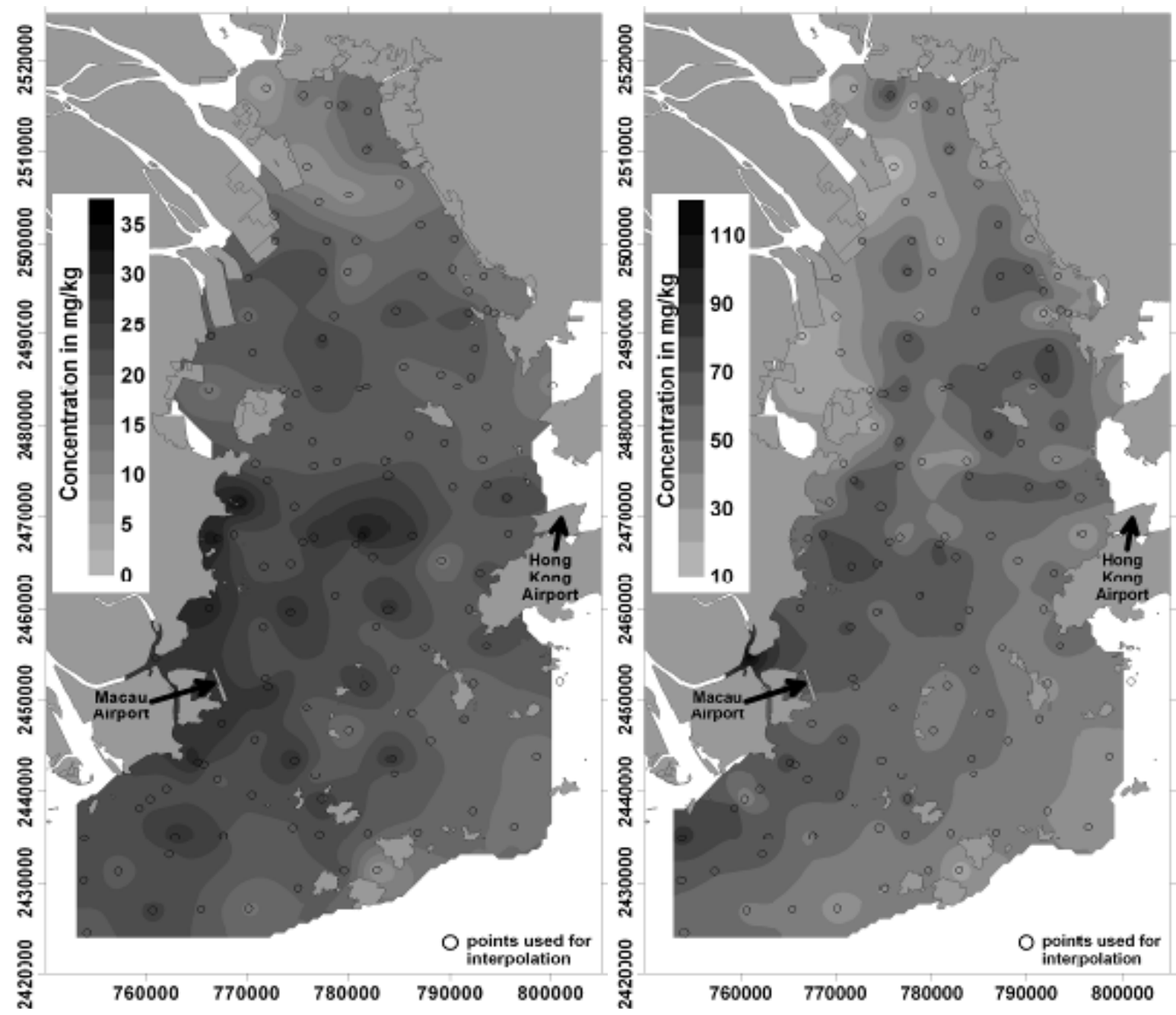

Figure 7. The distribution of $\mathrm{Co}$ (left), $\mathrm{Pb}$ (right) based on a composite data set.

The origin of $\mathrm{Al}_{2} \mathrm{O}_{3}, \mathrm{Ni}$ and $\mathrm{Cu}$ in the Pearl River Estuary is seen in rock and soil weathering. The concentrations of the geochemical parameters $\mathrm{Ni}$ and $\mathrm{Cu}$ reflect a natural and anthropogenic factor in the sediments (Bale et al., 2006). Out of these elements $\mathrm{Cu}$ originate from point sources (Liu et al., 2003).

Li et al. (2000) have analysed 21 core samples and found that $\mathrm{Pb}$ contents are enriched at almost each part of the estuary. This is supported by the results of this study. Furthermore, Li et al. (2000) gave a reason for the distribution of $\mathrm{Pb}$ in the sediments: it originates primarily from atmospheric input, and the input into the atmosphere is associated with the coal burning activities in the region. This is supported by Liu et al. (2003) who stated that $\mathrm{Pb}$ probably came from non-point sources into the estuary.

Zhou, Peng and Pan (2004) have measured the concentration of $\mathrm{Co}, \mathrm{Cu}, \mathrm{Ni}$ and $\mathrm{Pb}$ (Table 3 ) in the surface sediments at 12 sample stations. Excluding the extreme values measured in the
132 samples used in this work, the concentrations of these metals from both studies are similar.

To evaluate the enrichment of metals Peng et al. (2005) used $\mathrm{Fe}_{2} \mathrm{O}_{3}$ as conservative tracer to distinguish natural components from anthropogenic components. They could distinguish areas nearby $\mathrm{Hu}$ Men and one at the west coast of the estuary which show higher anthropogenic enrichment. This has been confirmed in this study. However, depending on the elements, there are more than just these two areas with anthropogenic enrichments as, e.g., the distribution of the standardised Co shows.

Wang et al. (2008) analysed the western part of the Pearl River Estuary. At MoDaoMen the areas of survey overlap. Wang et al. (2008) analysed as well $\mathrm{Co}, \mathrm{Cu}, \mathrm{Ni}$ and $\mathrm{Pb}$. Point 16 (outside MoDaoMen) from Wang et al. (2008) compared to this study show similar values in the concentrations of $\mathrm{Co}, \mathrm{Cu}$ and $\mathrm{Pb}$. In opposite to the Ni concentrations determined in this study which are around twice as high as the values from Wang et al. (2008). 

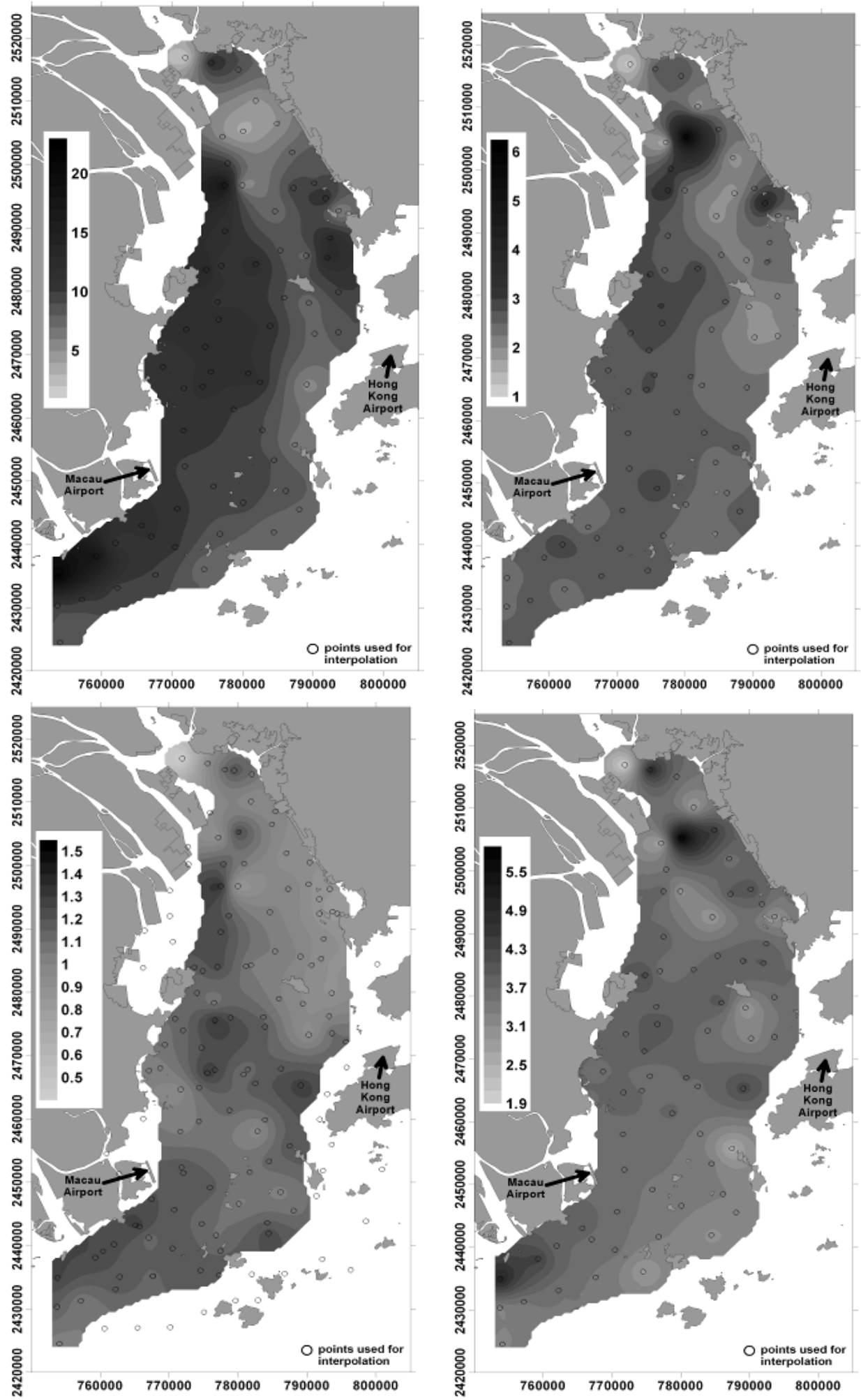

Figure 8. The distribution of $\mathrm{Hg}, \mathrm{Ni}$ (upper panel) and $\mathrm{Co}, \mathrm{Pb}$ (lower panel) standardised by $\mathrm{Al}_{2} \mathrm{O}_{3}$ based on data from IOW/SCSIO. 


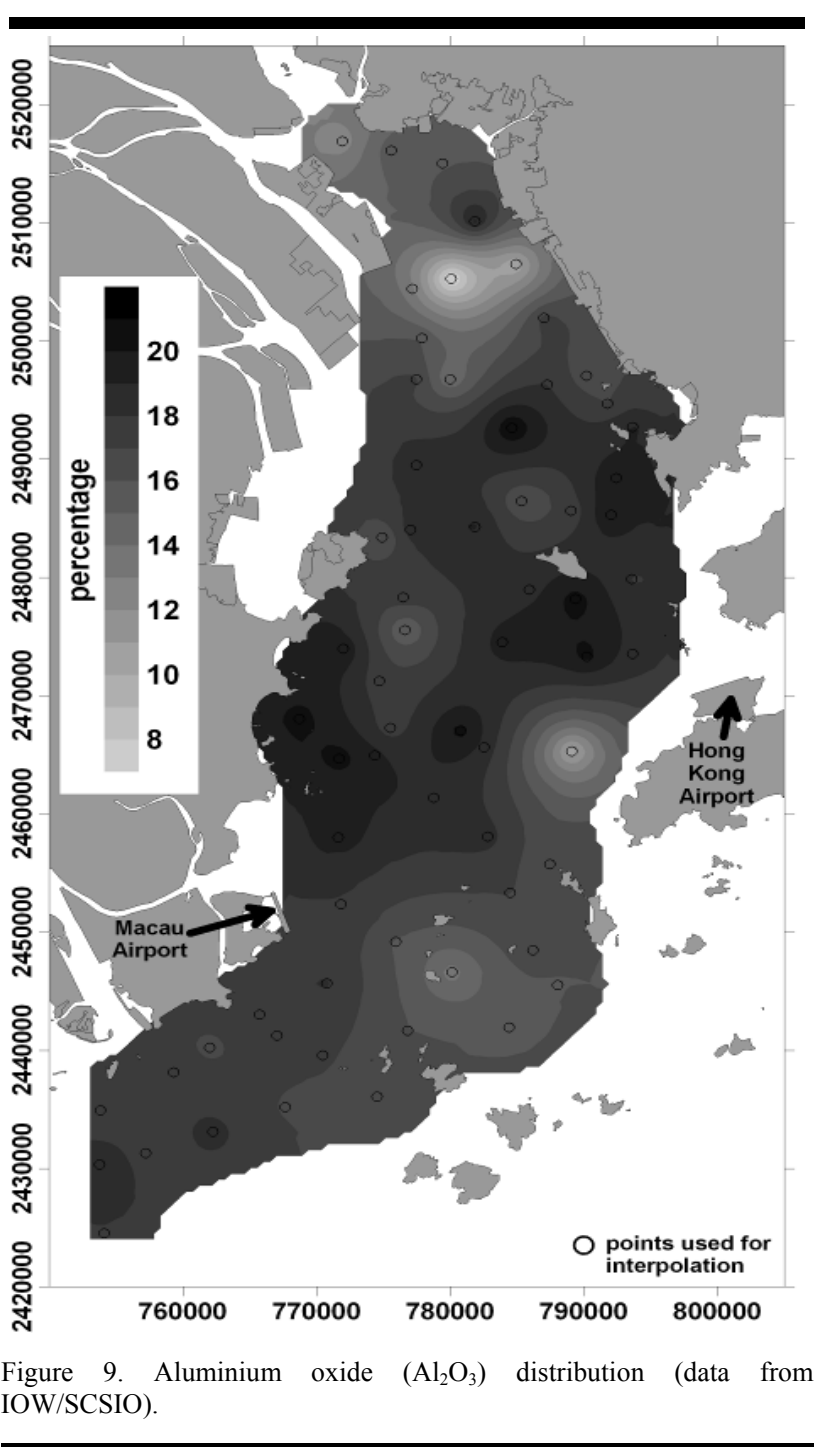

Table 4. Concentrations of trace elements in the Pearl River Estuary from this work and from Zhou, Peng and Pan (2004) (low $\left(2^{\text {nd }}\right)=2^{\text {nd }}$ lowest value, high $\left(2^{\text {nd }}\right)=2^{\text {nd }}$ highest value $)$.

\begin{tabular}{|c|c|c|c|c|c|}
\hline & & $\begin{array}{c}\mathrm{Co} \\
\mathrm{mg} / \mathrm{kg}\end{array}$ & $\begin{array}{c}\mathrm{Cu} \\
\mathrm{mg} / \mathrm{kg}\end{array}$ & $\begin{array}{c}\mathrm{Ni} \\
\mathrm{mg} / \mathrm{kg}\end{array}$ & $\begin{array}{c}\mathrm{Pb} \\
\mathrm{mg} / \mathrm{kg}\end{array}$ \\
\hline \multirow{6}{*}{ this study } & $\min$. & 5.0 & 8.8 & 11.6 & 9.9 \\
\hline & low $\left(2^{\text {nd }}\right)$ & 6.7 & 10.0 & 13.0 & 15.9 \\
\hline & & 29.6 & 88.0 & 57.8 & 78.2 \\
\hline & $\operatorname{high}\left(2^{\text {nd }}\right)$ & 31.4 & 146.6 & 61.1 & 79.2 \\
\hline & & 32.4 & 155.0 & 64.4 & 86.7 \\
\hline & $\max$ & 32.7 & 779.0 & 181.0 & 116.0 \\
\hline \multirow{2}{*}{$\begin{array}{l}\text { Zhou, } \\
\text { and } \\
(2004)\end{array}$} & $\min$. & 16.2 & 11.2 & 18.1 & 49.3 \\
\hline & $\max$. & 99.9 & 75.7 & 72.7 & 78.9 \\
\hline
\end{tabular}

\section{CONCLUSION}

The seafloor of the Pearl River Estuary was described by geochemical, granulometrical and geophysical parameters. The parameters have been derived from sediment samples taken by two joint cruises of the SCSIO (South China Sea Institute of Oceanology, Guangzhou, P.R. China) and the IOW (Leibniz Institute for Baltic Sea Research Warnemünde, Germany) in 2004 and 2005 (IOW/SCSIO data set). Furthermore, the GMGS (Guangzhou Marine Geological Survey) and the CCOST have provided additional geochemical and granulometrical data.

Aside from the calculations of the basic grain size parameters median and sorting, calculations and interpretations regarding the variety of geochemical parameters $(\mathrm{Hg}, \mathrm{As}, \mathrm{Ni}, \mathrm{Cu}, \mathrm{Co}, \mathrm{Pb}$, $\mathrm{Cr}, \mathrm{Sr}, \mathrm{Zn}, \mathrm{Zr}, \mathrm{Ba}, \mathrm{Ga}$ and $\mathrm{Cd}$ ) have been done.

No recent distribution maps of sediment parameters with a comparable extent and amount of different parameters presented in this work can be found in the recent scientific literature. Therefore, these maps are a completely new contribution to the latest research in the Pearl River Estuary.

For the geochemical parameters, the different data sets IOW/SCSIO and the one from the GMGS were merged for combined investigations. The non-parametrical KolmogorovSmirnov distribution test (K-S Test) has been deployed which confirms the compatibility of the datasets.

The concentrations and spatial distributions of the geochemical parameters $\mathrm{As}, \mathrm{Co}, \mathrm{Cu}, \mathrm{Hg}, \mathrm{Ni}$ and $\mathrm{Pb}$ have been observed. This has been done for the LingDingYang Estuary in an extent which could not be found in the recent literature. Main results are the new spatial distributional patterns of these geochemical parameters. As, $\mathrm{Co}, \mathrm{Cu}, \mathrm{Hg}$ and $\mathrm{Ni}$ concentrations mainly decrease to the more marine influenced southeastern parts and show a higher concentration in the central part and at the western shoals of the estuary. This indicates that the distribution patterns are mainly dominated by the fluvial input and the hydrodynamics of the estuary. Hereby, $\mathrm{Hg}$ is supposed to be brought into the coastal zone and Pearl River Estuary through the outlet MoDaoMen and from the offshore area around Macau. In contrary, As enters the estuary through all outlets. $\mathrm{Cu}$ and $\mathrm{Ni}$ show a hotspot in the northeastern part of the estuary. The source could not been identified, but it can be assumed that the input comes from the industrial parts of the DongGuan city. These high total concentrations of $\mathrm{Cu}$ and $\mathrm{Ni}$ are not expected to be analytical mistakes due to the different procedures of measurement. Furthermore, $\mathrm{Cu}$ as a rock-forming element and as an independent mineral enters the estuary by the rivers. Therefore, the total concentrations of $\mathrm{Cu}$ are higher at the western shoals compared to the rest of the investigation area due to the main water outflow of the estuary. $\mathrm{Ni}$ is supposed to originate from the ZhuHai area and via sediment transport from JiaoMen.

Co shows higher concentrations in the fine sediments close to the outlets and along the sediment transport pathways.

$\mathrm{Pb}$ shows low concentrations at the outlets of the LingDingYang Estuary and relatively higher concentrations within the rest of the estuary. Therefore, the input is assumed to be aerial.

Additionally, some geochemical parameters ( $\mathrm{Hg}, \mathrm{Ni}$, $\mathrm{Co}$ and $\mathrm{Pb}$ ) have been standardised by aluminium oxide. This has been 
done for parameters from the IOW/SCSIO data set only due to the missing measurements of aluminium oxide in the GMGS data set. The standardisation has been done to equalise the dilution effects of sediment constituents like siliceous minerals where almost no metals are bound to. Therefore, an evaluation of the relative input of trace elements has been done. By doing so, a location in the North of the estuary in a fine-sand area with assumed larger anthropogenic influences was identified by the geochemical parameters $\mathrm{Ni}$ and $\mathrm{Pb}$. Otherwise, no significant differences between the standardised and non-standardised spatial distribution patterns of the considered geochemical parameters have been found.

\section{ACKNOWLEDGMENTS}

We want to thank Zheng Zhichang and his team from the Guangzhou Marine Geological Survey (GMGS), Guangzhou, China, Dr. Torsten Seifert (IOW, Baltic Sea Research Institute, Germany), the team from Prof. Zhou Di (SCSIO), Prof. Wu ChaoYu and his team (especially Ren Jie) from the Center of Coastal Ocean Science and Technology (CCOST), Guangzhou, China, Dr. Wolfram Lemke $(\dagger)$, Dr. Thomas Leipe, Dr. Franz Tauber, Dr. Rudolf Endler, Prof. Michael Böttcher, Prof. Detlef Schulz-Bull and Dr. Hans-Ulrich Lass (IOW). For the measurements of the sediment parameters we want to thank Peter Rückert (IOW, Rostock) and Dr. Shi Qi (SCSIO, Guangzhou).

\section{LITERATURE CITED}

Aitchison, J., 1986. The Statistical Analysis of Compositional Data. London: Chapman \& Hall, 416p.

Aitchison, J.; Barcelo-Vidal, C.; Martin-Fernandez, J.A., and Pawlowsky-Glahn, V., 2000. Logratio analysis and compositional distance. Mathematical Geology, 32(3), 271275.

Bale, A.J.; Widdows, J.; Harris, C.B., and Stephens, J.A., 2006. Measurements of the critical erosion threshold of surface sediments along the Tamar Estuary using a mini-annular flume. Continental Shelf Research, 26(10), 1206-1216.

Bobertz, B. and Harff, J., 2004. Sediment facies and hydrodynamic setting: a study in the south western Baltic Sea. Ocean Dynamics, 54(1), 39-48.

Bobertz, B., 2000. Regionalisierung der sedimentären Fazies der südwestlichen Ostsee. Dissertation Thesis, Ernst-MoritzArndt University, Greifswald, 133p.

Bohling, G.C.; Davis, J.C.; Olea, R.A., and Harff, J., 1998. Singularity and nonnormality in the classification of compositional data. Mathematical Geology, 30(1), 5-20.

Cao, W.Z. and Wong, M.H., 2001. Pearl River Delta. In: M. Scheffers and J. Sorensen (eds.), Report of the Workshop on the Planning and Management of Modified Mega Deltas. The Hague, The Netherlands, pp. A41-A45.

Chen, G.N.; Zhang, K., and He, X.K., 1994. Paleo-geographic evolution of the Pearl River Delta since the late Pleistocene. Quaternary Sciences, 1, 67-74.

Chen, J.C. and Heinke, G.W., 2001. Pearl River Estuary Pollution Project (PREPP). A Chief Executive's Community
Project Summary Report. Hong Kong: University of Science and Technology, 122p.

Chen, F.; Yang, Y.; Zhang, D., and Zhang, L., 2006. Metals associated with reduced sulfur in sediments from different deposition environments in the Pearl River estuary, China. Environmental Geochemistry and Health, 28(3), 265-272.

Deutsch, C.V. and Journel, A.G., 1992. GSLIB - Geostatistical Software Library and User's Guide. New York: Oxford, $340 \mathrm{p}$.

Dong, L.; Su, J.; Ah Wong, L.; Cao, Z., and Chen, J.-C., 2004. Seasonal variation and dynamics of the Pearl River plume, Pearl River Estuary Study. Continental Shelf Research, 24(16), 1761-1777.

Folk, R.L. and Ward, W.C., 1957. Brazors River bar: a study in the significance of grain-size parameters. Journal of Sedimentary Petrology, 27(1), 3-26.

Harff, J.; Leipe, T., and Zhou, D. (eds.), (2010). Pearl River Estuary related sediments as response to Holocene climate change and anthropogenic impact (PECAI). Journal of Marine Systems, 82(1), 1-2.

Heise, B.; Bobertz B., and Harff, J., (2010). Classification of the Pearl River Estuary via Principal Component Analysis and Regionalisation. Journal of Coastal Research, 26(4), 769779 .

Heise, B.; Harff, J.; Ren, J., and Liang, K., (2010). Pattern of potential sediment erosion in the Pearl River Estuary. Journal of Marine Systems. 82(1), 62-82.

Huang, G.Q., 2000. Holocene Records of Stroms in Sediments of the Pearl River Estuary and Vicinity. Dissertation Thesis, The University of Hong Kong, Hong Kong, 206p.

Hurvich, C.M., 1989. Regression and time Series model selection in small samples. Biometrica, 76(2), 297-307.

Journel, A.G. and Huijbregts, C., 1978. Mining Geostatistics. London: Academic, 600p.

Li, X.; Wai, O.; Li, Y.; Coles, B.; Ramsey, M., and Thornton, I., 2000. Heavy metal distribution in sediment profiles of the Pearl River estuary, South China. Applied Geochemistry, 15(5), 567-581.

Lin, H.Y.; Han, W.Y., and Ma, K.M., 1990. Preliminary research on water exchange at the Pearl River estuaries. Chinese Science Bulletin, 35(18), 1547-1551.

Liu, W.X.; Li, X.D.; Shen, Z.G.; Wang, D.C.; Wai, O.W.H., and Li, Y.S., 2003. Multivariate statistical study of heavy metal enrichment in sediments of the Pearl River Estuary. Environmental Pollution, 121(3), 377-388.

Olea, R.A., 1999. Geostatistics for Engineers and Earth Scientists. Dordrecht: Kluwer, 328p.

Peng, X.; Zhang, G.; Mai, B.; Hu, J.; Li, K., and Wang, Z., 2005. Tracing anthropogenic contamination in the Pearl River estuarine and marine environment of South China Sea using sterols and other organic molecular markers. Marine Pollution Bulletin, 50(8), 856-865.

Shi, Q.; Leipe, T.; Rückert, P.; Zhou, D., and Harff, J., (2010). Geochemical Composition, Provenance, Deposition and Enrichment of Short Sediment Cores from the Pearl River Estuary, Southern China. Journal of Marine Systems, 82(1), $28-42$.

Surfer ${ }^{\circledR}, 2004$. Surfer, Surface Mapping System for Windows. Surfer Version 8.05, Golden Software, Inc. 
Tauber, F. and Emeis, K.-C., 2005. Sediment mobility in the Pomeranian Bight (Baltic Sea): a case study based on sidescan-sonar images and hydrodynamic modelling. GeoMarine Letters, 25(4), 221-229.

Tauber, F., 1995. Characterization of grain-size distributions for sediment mapping of the Baltic Sea bottom. The Baltic 4th Marine Geological Conference, (SGU/Stockholm Center for Marine Research, Uppsala), poster.

Tauber, F., 1997. A numerical and practical test of ternary diagrams for grain-size data classification. In: V. Pawlowsky-Glahn (ed.), Proceedings of IAMG'97, The Third Annual Conference of the International Association for Mathematical Geology. Barcelona/ Spain, pp. 186-191.

Tauber, F., 1999. Spurious clusters in granulometric data caused by logratio transformation. Mathematical Geology, 31(5), 491-504.

Tauber, F., 2002. How to convert incompatible granulometric data into comparable clastic sediment maps. In: E.M. Emelyanov (ed.), The Baltic 7th Marine Geological Conference. Kaliningrad. Russia: Atlantic Branch of P.P. Shirshov Institute of Oceanology RAS, 129p.

Wang, H.Q.; Lau, K.H., and Chan, W.M., 2002. A PC based Visualization System for Coastal Ocean and Atmospheric Modelling, http://hqlx20.ust.hk/.
Wang, S.; Cao, Z.; Lan, D.; Zheng, Z., and Li, G., 2008. Concentration distribution and assessment of several heavy metals in sediments of west-four Pearl River Estuary. Environmental Geology, 55(5), 963-975.

Wu, C.Y., 2002. The Pearl River estuary under global changes and its experimental observing system. LOICZ Reports \& Studies, 26, 112-117.

Yan, G.; Li, C.; Lo, Z., and Ying, Z., 1994. Studies on Hydrodynamic Geomorphology and their Application to Habour Construction in South China. Guangzhou: Zhongshan University Press, 313p.

Yuan, J.Y.; Zhao, H.T.; Lu, T.S.; Song, C.J., and Zhang, Q.M., 1994. Dynamic Geomorphic Systems of South China Coast. In: Zhou, D.; Liang, Y.B., and Zeng, C.K. (eds.), Oceanology of China Seas. Dordrecht: Kluwer, pp.465476.

Zhao, H., 1990. The Evolution of Pearl River Estuary. Beijing: Ocean Press, 357p.

Zhou, H.; Peng, X., and Pan, J., 2004. Distribution, source and enrichment of some chemical elements in sediments of the Pearl River Estuary, China. Continental Shelf Research, 24(16), 1857-1875. 